\title{
Consumption Preference of Foreign Pasta in Eastern Ethiopia: A Household Analysis in Dire Dawa City
}

\author{
Muhammed Hamza Ali \\ Department of Economics, Dire Dawa University- Ethiopia \\ BANBUL SHEWAKENA \\ Department of Management, Dire Dawa University, Ethiopia
}

\begin{abstract}
Consumer preferences are defined as the subjective (individual) tastes, as measured by utility, of various bundles of goods. They permit the consumer to rank these bundles of goods according to the levels of utility they give the consumer. Researchers have examined the Consumers' preference related to their attributes for imported and local Products in Dire Dawa City Administration taking pasta as case study. Probabilistic multistage sampling is identified as a means of collecting data from appropriate sampling units. Both qualitative and quantitative analytical techniques used for analyzing the collected data. Simple statistical techniques and logical data analysis/ narrative analysis were used for qualitative data as of necessary. The quantitative techniques employed descriptive statistics and supported by inferential statistics like t-statistic value and $\boldsymbol{N}^{2}$ statistic value and ANOVA. STATA12 will be taken for processing and analyzing of data.In the study, households mostly prefer and purchase Badrya(96\%) and Bahir (92\%) pastas relative to other types consistently more than three years. households prefer forein pasta foods because have best and wanted attributes. Thus their attributes of safe for cooking, easily available in the market, attractive style and structure, sweetness, and safe for eating are main factors for the preference of foreign pasta.
\end{abstract}

Keywords: Consumption preference, Dire Dawa City, and Past types

DOI: $10.7176 / \mathrm{JAAS} / 53-02$

Publication date:March $31^{\text {st }} 2019$

\section{Introduction}

Consumers choose the best bundle of goods they can afford (Varian, 1999). Consumers are individuals and households that buy the firms product for personal consumption (Kotler, 2004). It often used to describe two different kinds of consuming entities: the personal consumers and the organizational consumers (Krishna, 2010). The activities these consumers undertake when obtaining, consuming, and disposing of products and a service is known as consumer behavior. When a consumer wanted to make the purchase decision, they will pass through many like recognition, getting information, evaluation, purchase, feedback (Blackwell, Miniard, and Engel, 2006).

When a consumer choose a product or brand to consume from various choices in the market, many factors appear to affect his/her buying behavior due to the diverse environmental and individual determinants. It is believed that the consumer's behavior to local produced goods and services is considered as key determinants of the economic growth and development of a nation (Shapiro P, 2013). However, Studies of Robert A .and Patrick A (2009); and Saffu and Walker (2006) indicated that consumers have been exposed to foreign alternatives for domestic made products and foreign products due to the increase in imported goods and high competitive consumers markets in Africa.

Thus the switch of consumer's preference to foreign made foods forced policy makers and business decision agents to deal with consumer's behavior as it has great influence in the expansion of industries and macroeconomics of the country. A number of factors could explain consumer's preference for a specific brand of goods whether local or foreign. The determinate factors, however, to a given food item vary from country to country particularly in Africa (see Kassali et al, 2012; Asante et al, 2013; Nwanze et al, 2006; and Tomlins et al., 2005).

\section{Research Background}

The attempt of Consumers' behavior to satisfy their own needs has am implication in the economy of a country in general and in developing country like Ethiopia in particular. Because industries in these countries are not much enough mature to compete with foreign industries producing the same type of foods which again drags local producers to change their market decision and affect the country's trade balance.

Though a numbers of reasons had been attributed to consumer's shift towards foreign made foods, technologically advanced, stylish and competitively priced, taste, superior quality, imported brand names, awareness about the imported products, sense of proud and group references were taken as major causes 
(Omotayo O, 2009, Shapiro P, 2013 and Nanzia F, 2014).

Consumers' demand for foreign products in Ethiopia particularly in Dire Dawa Administration is too strong especially with regard to food items (rice, pasta, milk, food oil, and others); cosmetics products, electronic materials; and clothes. Different reasons could be motioned including the town's proximity to other countries like Djibouti, and Somalia.

The Dire Dawa project Profile (2013) showed that there is big gap between demand of pasta and supply of pasta leaving the demand side to exceed. The projection, during 2008-2020, also indicated that foreign made foods will have an increasing market share in the local economy. This could not only be due to shortage of the locally produced foods but also the paradigm shift of consumer's preference towards foreign made foods. The researchers' pilot survey in the area (2015) also confirmed that most consumers have strong preference for foreign pasta products which have been available for more than 5 (five) years.

Studies in Ethiopia marginalize why local consumers prefer foreign food items when the local product is cheap and easily available. One can look many studies conducted, in Ethiopia, with consumer preference have focused on products other than food items. For instance, Dejene M (2012) studied on preference determinant factors for Addis Ababa Restaurants. The preference of foreign product is studied by Mesay Sata (2013) who focused on factors that affect the purchase decision of mobile phone in Hawasa town and Sirwa Migbaru (2014) that concentrate on factors that affect preference of forein shoes and cloth in Gonder town.

The researchers are motivated to conduct this study believing that: one consumer's preference is the first issue in the process of policy formation especially in transitional economies like Ethiopia/Dire Dawa; second serve as reference for further researches in the area as priority researches in Ethiopia have focused on cloth and shoes types leaving food items untouched. Therefore this study focused on examining the reasons why consumers prefer foreign pasta products over locally produced pasta foods.

\section{Determinants of preference of imported products in Africa}

In the global world we are living where crises deepen and competition gets fierce, consumers are becoming more and more important (Durmaz Y. and Sebastian J, 2012). It is believed that the consumer's behavior to locally produced goods and services is considered as key determinants of the economic growth and development of a nation (Shapiro P, 2013).

Studies indicated that consumers have been exposed to foreign alternatives due to the increase in imported goods and high competitive consumers markets in Africa. As per Robert A and Patrick A (2009), consumers have been demanding the same quality of goods available in developed countries due to the increase in travel and education as well as improvements in communication such as the global-spanning television network and the internet as a convergence of taste and preference. Specifically technologically advanced, stylish and competitively priced, taste, superior quality, imported brand names, awareness about the imported products , sense of proud and group references were identified by Omotayo O. (2009), Shapiro P. ( 2013), and Nanzia F. (2014) as major shifting factors towards foreign made foods.

On the other hand Gideon et al (2014) and Musa et al (2013) pointed out that poor packaging, price, Flavor and taste were the main reason which inhibits consumers' choice of locally produced food item. Similar to other African countries, studies conducted in Ethiopia also share similar reasons for preference of foreign products. For instance the study of Siraw M. (2014) on the preference of imported shoes and close products in Gonder town conclude that fashionably and qualities were the basic reasons for preference of foreign products. On the other hand, the study of Mesay S and Simret B (2013) in mobile preference concluded that price and style of the products were the causes of selecting foreign mobile devices.

\section{Research Methodology}

\subsection{The study area}

This study was conducted in Dire Dawa city of Ethiopia. Dire Dawa is believed to be one of the biggest economic corridors of eastern Ethiopia. The city is most strategic for economic as well as political spheres of the region due to its proximity to Djibouti because the city is located around $515 \mathrm{KM}$ far from the capital city, Addis Ababa and $333 \mathrm{Km}$ from the international port of Djibouti. Geographically, it is located in the eastern part of the country specifically lying between 900 27' and 900 49'N latitudes and between $410038^{\prime}$ and 4200 19'E longitudes. Dire-Dawa is the second chartered city next to Addis Ababa with two layers of governance, the Administration's government at the top and 9 urban and 38 rural Kebeles at the bottom. The total area of the administration is 128,802 ha $(1977 \mathrm{~km} 2)$ and the Administration shares common boundaries with Somali National Regional States in the West, North and East and with the Oromia National Regional State in the South.

Dire-Dawa is with total population of 341,834 out of which the urban population was $233,224(67.5 \%)$ and that of the rural population was 108,610 (32.5\%) (DDAEPA, 2011). The population made up of people of different culture and socio-economic background. In the city more than $7 \%$ of economic activity dominated by trade and industrial outputs 
Figure 3.1. Map of Dire Dawa Administration Showing the sections of Kebelles

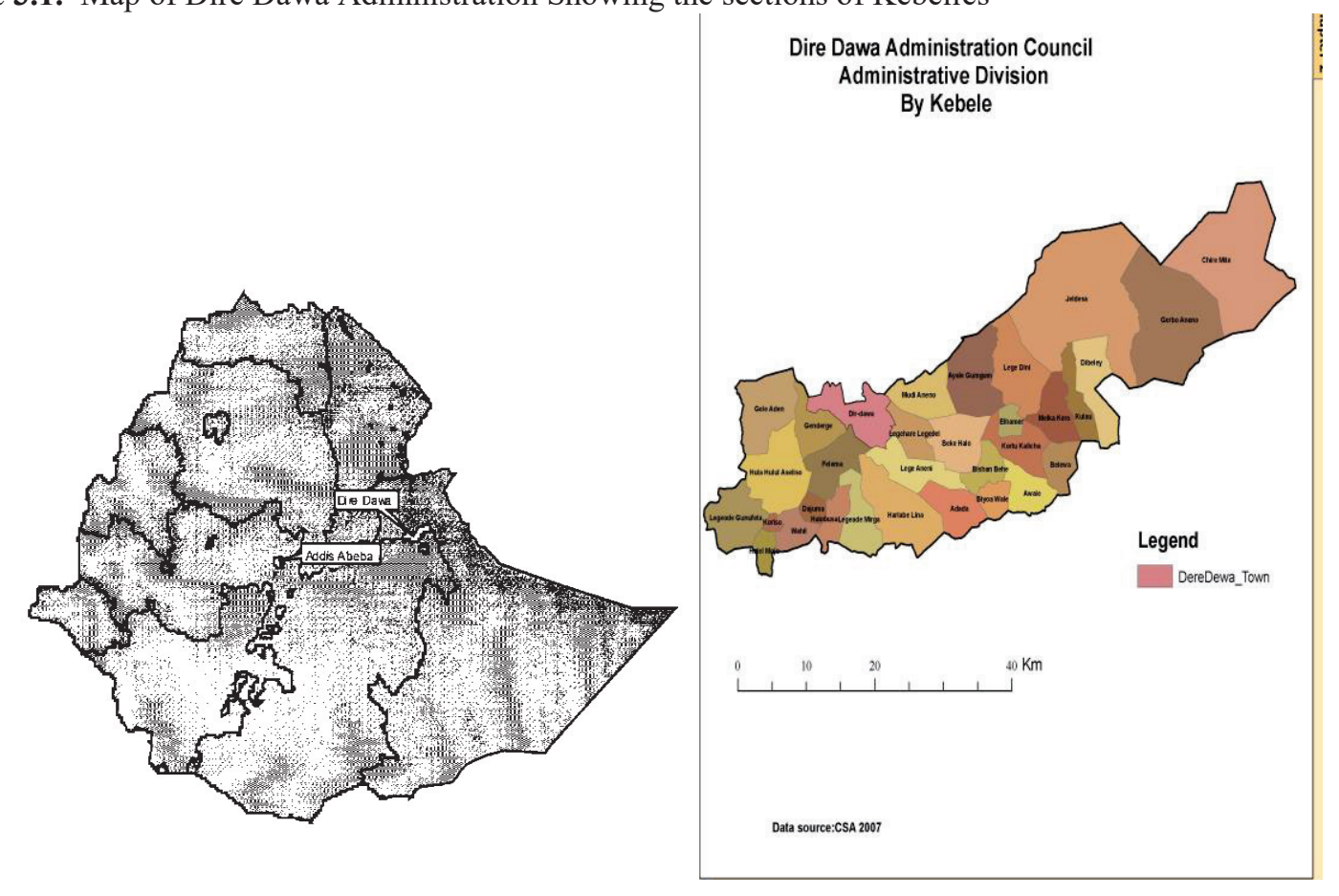

\subsection{Data collection}

The study was conducted in the households living in 9 urban kebeles of Dire Dawa Administration. 299 samples selected randomly are used for this study. In order to capture the objectives, primary source of data is collected through well-designed and administered structured questionnaire from housewives (buying decision maker).

For the purpose of increasing reliability and validity of the information we surveyed only individuals who are responsible in buying and cooking the family's food, conducted the survey during weekends (Saturday afternoon and Sunday), gave training for numerators, and finally making pilot survey were the main tasks done before data collection.

\subsection{Sample size}

The study was carried out in eastern urban area of Ethiopia particularly in Dire Dawa city Administration, which is one of the largest cities in eastern Ethiopia. In the city pasta consumption is most consumption habit similar to other cities found in the area, participants are selected randomly. Following Besir Koc.et al (2014), the sample size required to represent the study was determined using the following formula. $\mathrm{n}=\mathrm{t}^{2}[1+(0,02) *(\mathrm{~b}-1)]^{*} \mathrm{p} * \mathrm{q} / \mathrm{e}^{2}$

When $b=1$, the equation would be

\section{$\mathrm{n}=\left(\mathrm{t}^{2} / \mathrm{e}\right)^{2}\left[{ }^{*} \mathrm{p} * \mathrm{q}\right.$}

Where $n$ : sample size, $t$ : confidence interval (95\%), b: sampling process, $\mathrm{p}$ : realization probability of the analyzed unit in the population, q: the non-realization probability of the analyzed unit in the population, and e : error calculated based on

$$
e=\frac{\sqrt{t^{2} * \mathrm{p} * \mathrm{q}}}{\mathrm{n}}
$$

For the purpose of maximizing sampling volume in the study, $\mathrm{p}$ and $\mathrm{q}$ values were taken as $50 \%$. Thus the sample size required to study was determined as 353 sample units.

Though pasta consumption is common in all areas of the city, the socio-economic structure of different ethnicity could vary the intensity of consumption habit of people. Based on this intensity, we stratified people of Kebele-2, Kebele-3 and Kebele-4 as strata 1. While kebele- 5, $6 \& 7$ are grouped in starat-2, the remaining kebeles (kebele-1, 8 \&9) are categorized under starta-3.Following the Neyman (1995) optimal allocation, the proportional allocation of sample size is given as :

$\boldsymbol{n}=\sum_{i=1}^{m} N i \frac{\text { piqi }}{N S 2 s s}=$ 
Where $\mathrm{p}_{\mathrm{i}}$ is the proportion in the ith stratum, and $\mathrm{qi}=(1-\mathrm{P})$.

Now in the absence of information about the stratified sample variance,S2, for each stratum, we assumed same variance is to be for all stratum.

The Neyman allocation for such kind would take the form of;

$\boldsymbol{n}=\mathrm{nNi} / \boldsymbol{n}=\mathbf{3 5 3}$; Where ni is proportional to Ni. It means that the sample is allocated to the different strata in proportion to the number of sub-population units.

\subsection{Sampling techniques}

In view of the consumption of habit of the people under consideration, people of the city in all kebeles have a habit of consuming pasta, macaroni and rice. However people of each kebele has different characteristics is different from others kebeles at least in socio-economic dimension. Thus multistage sampling is identified as a means of collecting data from appropriate sampling units. Cluster sampling, stratified sampling and simple random sampling (via systematic method) were employed step by step.

\subsection{Method used for Analysis}

Due to the nature of the objectives, we adopted descriptive method of analysis. Because to deal with perceptions of respondents to the foreign /and local type of pasta products we used simple statistical tools; percentages, ratios, average (Mean) as measures of central tendencies and standard deviation as dispersions.

On the other side an inferential statistics has been used to examine the statistical association between various attributes of pasta product and respondent's socio- demographic characteristics. Specifically we utilized inferential statistics such as t-statistic value and $\mathrm{x} 2$ statistic value and ANOVA.

\section{Results and Discussion}

\subsection{Descriptive Analysis}

\subsubsection{Descriptive statistics of the sample}

Of the total of 355 questionnaires is distributed, only $85.63 \%$ are returned. Nor-respondents are $18.60 \%$. Though $81.40 \%$ are assumed to be responded, but only $63.5 \%$ are used for analysis.

The age of respondent lays between 30 to 50 and most of them are married. Majority of respondents' job is house wife's (34\%) followed by NGO and government employee respectively. The income of the majority of house hold found between 1651-3200 followed by 5251-7800 Birr (See in appendix 1 Table 1: Description of data).

\subsubsection{Preference and markets of Pasta products}

In this part the, most familiar, preference and demand of pasta products are examined. The type of pasta products considered in this study are those that are often available, at least three years \& above, in the area and currently used products. We tried to consider other new type of products during and after the survey period (JuneDecember, 2017) but nothing has appeared in the market.

In the study, we found that more than $75 \%$ of the households consume pasta three -to- four times per week with significant volume of purchase, 3 packets per week. The survey also indicated that more than $85 \%$ of the samples bought pasta products mainly from main distributers found in ASHEWA/Ruztera and local shops. This guides us to say that pasta product is one of the most market foods item in the region.

Respondents were asked to report how long frequently purchased pasta products available to them in the market. Of the seven choices of pasta products, Bahr (48\%-75\%), Golda (50\%-63\%), and Roza (30\%-50\%) are relatively most frequently purchased pasta products. But Bedria (69\%-94\%) is the most highly preferred and frequently demanded type of pasta.

As per the table below, the afro mentioned pasta types are the most demanded ones relatively to other options in the market. In general the local one - vera pasta $(24 \%)$ and mawel $(25 \%)$ are the least preferred pasta products relative to other options. Badrya $(96 \%)$ and Bahir $(92 \%)$ are highly demanded and preferred pasta products. $80 \%$ of the respondents indicated that their preferred consumption habit was stayed between one and 3 years. 
Table 2: Demand of past types

\begin{tabular}{|lllllll|} 
& $\begin{array}{l}\text { Toofrequently } \\
\text { Demanded }\end{array}$ & $\begin{array}{c}\text { Frequently } \\
\text { Demanded }\end{array}$ & $\begin{array}{l}\text { Moderately } \\
\text { Demanded }\end{array}$ & $\begin{array}{l}\text { Less } \\
\text { frequently } \\
\text { demanded }\end{array}$ & $\begin{array}{l}\text { Never } \\
\text { demanded }\end{array}$ & $\begin{array}{l}\text { Total } \\
\text { demand }\end{array}$ \\
\hline VERA & $10(7.35 \%)$ & $5 / 3.63 \%$ & $18 / 13.24 \%$ & $42 / 30.88 \%$ & $61 / 44.85 \%$ & $24.26 \%$ \\
\hline AYAN & $12(9.60 \%)$ & $29 / 23.20 \%$ & $26 / 20.30 \%$ & $19 / 15.20 \%$ & $39 / 31.20 \%$ & $53.60 \%$ \\
\hline ROZA & $25(20.33 \%)$ & $36 / 29.27 \%$ & $20 / 16.26 \%$ & $22 / 17.89 \%$ & $20 / 16.26 \%$ & $65.85 \%$ \\
\hline BAHR & $45(27.11 \%)$ & $80 / 48.19 \%$ & $28 / 16.87 \%$ & $5 / 3.01 \%$ & $8 / 4.82 \%$ & $92.17 \%$ \\
\hline GOLDA & $34(25.37 \%)$ & $66 / 48.51 \%$ & $22 / 16.24 \%$ & $4 / 2.99 \%$ & $9 / 8.72 \%$ & $90.30 \%$ \\
\hline BEDRIA & $111(68.52 \%)$ & $43 / 26.54 \%$ & $2 / 1.23 \%$ & $2 / 1.23 \%$ & $4 / 2.47 \%$ & $96.30 \%$ \\
\hline MAWE & $10(10.53 \%)$ & $10 / 10.53 \%$ & $14 / 14.74 \%$ & $14 / 14.74 \%$ & $47 / 49.47 \%$ & $35.79 \%$ \\
\hline
\end{tabular}

Source: own computation , 2017 survey

\subsection{Determinants of pasta preference}

\subsubsection{Inferential analysis}

The ANOVA result of the survey indicated that the preference of Vera pasta is influenced by the job type of wife's and household income. As income of the household increase peoples preference would like to increase preference of Vera pasta. In a similar fashion, it is found that the transfer of job type from being housewife to employee is likely to increase house hold's preference of Vera pasta products. People's perception about rich in content, consumption conformability and structure of Vera pasta products significantly influence consumers' Vera pasta preference. People's demographic characteristics and attractiveness of Vera pasta, in terms of content $\&$ consumption conformability, were the most important attributes which influence local consumers towards local pasta products.

The preference of foreign pasta products, specially Ayan, Bahir, and Roza, are found to be affected by consumers' perception about their internal ingredients. Perception about richness in content is found to be significant to affect demand for Ayan and Roza type of pasta products. Conformability in consumption is the most important factor which significantly affects the preference of Bahir, Bedrya, and Roza pasta products. Bedrya pasta is also influenced by the increase in education of wife/mothers.

Other pasta products frequently available in the local market such as Mawel and Golda pasta types could not found to be affected by identified factors. Though they are demanded by consumers relative to local Vera pasta, we did it find any peculiar factors associated with these pasta products.

Table 3:- Determinants of pasta preference

\begin{tabular}{|c|c|c|c|c|c|c|c|}
\hline & VERA & AYAN & ROZA & BAHIR & GOLDA & BEDRYA & MAWEL \\
\hline Variables & Prob $>$ chi2 & Prob $>$ chi2 & Prob>chi2 & Prob $>$ chi2 & Prob>chi2 & Prob>chi2 & Prob $>$ chi2 \\
\hline $\begin{array}{l}\text { Weekly } \\
\text { consumption }\end{array}$ & 0.3155 & 0.1998 & 0.615021 & 0.112823 & 0.8760927 & 0.9827 & 0.9133 \\
\hline $\begin{array}{l}\text { Job type of } \\
\text { wife }\end{array}$ & 0.0836 & 0.9804 & 0.4872 & 0.811 & 0.811 & 0.725 & 0.6667 \\
\hline $\begin{array}{l}\text { House hold } \\
\text { income }\end{array}$ & 0.0354 & 0.0417 & 0.6621 & 0.4011 & 0.9829202 & 0.9317 & 0.8438 \\
\hline Wife education & 0.4766 & 0.1998 & 0.615 & 0.8154 & 0.987212 & 0.0207 & 0.6667 \\
\hline Household size & 0.223 & 0.5806 & 0.788321 & 0.9488 & 0.721531 & 0.4173 & 0.9201 \\
\hline $\begin{array}{l}\text { Perception of } \\
\text { comfort ability }\end{array}$ & $\mathbf{0}$ & 0.7635 & 0.8456 & 0.0659 & 0.806 & 0.8075 & 0.193 \\
\hline $\begin{array}{l}\text { Perception } \\
\text { about safety } \\
\text { for cooking }\end{array}$ & 0.1067 & 0.0526 & 0.4411 & 0.4085 & 0.7999 & 0.035 & 0.883 \\
\hline $\begin{array}{lr}\text { Belief } & \text { about } \\
\text { richness } & \text { in } \\
\text { content } & \\
\end{array}$ & 0.053 & 0 & 0.0282 & 0.22 & 0.1152 & 0.029 & 0.691 \\
\hline $\begin{array}{l}\text { Belief about } \\
\text { good in style \& } \\
\text { structure }\end{array}$ & $\mathbf{0}$ & 0.389 & 0.3709 & 0.0861 & 0.533 & 0.347 & 0.707 \\
\hline
\end{tabular}

Source: own computation, 2017 survey 


\subsection{Conclusion, Recommendation and Policy Implication \\ 3.3.1. Conclusion}

The descriptive statistics showed that Bahr (48\%-75\%), Golda (50\%-63\%), and Roza (30\%-50\% are relatively most frequently purchased pasta products. But Bedriya (69\%-94\%) is the most highly preferred and frequently demanded type of pasta.

The study also found most consumers $(>35 \%)$ is demand more than 3 packet per week. This indicated that consumption habit of most people is too large. The study indentified that consumers purchase their pasta demands mostly in Local shop ( $>40 \%)$, Ashewa/Ruztera $(>45 \%)$. Here households who bought out of Dire Dawa and Super markets are too few $(<4 \%)$. This indicates that pasta markets in the region are highly domestic.

We found also that brand/names \& familiarity of pasta / have an effect on demand of pasta consumption, $78 \%$. The households believed that foreign pasta products have characteristics of attractive structure and have attractive style $(68.01 \%)$, they are tasty $(84.69 \%)$, have Social privileges $(88.84 \%)$, and are Comfort in consumption(66.83\%). One can see that characteristics of pasta products such as their shape, tastiness, and comfort in consumption matter for people's preference.

For the issue of why foreign pasta products are most likely have best and wanted attributes, we found that, among others, Bedria, Bahr, and Golda are most wanted type of pasta products. It is due to because people believe that they are Safe for cooking, easily available in the market, Attractive style and structure, Sweetness, Safe for eating and Affordable. Of the three, Golda and Bahr are known with the "rich in content and familiar in the household" characteristics. Some type of pasta items including VERA, Mawel and Roza pasta products are known with poor characteristics such as Poor sweetness, Inaccessible in the market, Unsafe for youths and elites and Not safe for eating.

\subsubsection{Recommendation and policy implication}

Based on the result of the research the following recommendations are forwarded by the researchers. Local pasta product is the least preferred by females and elites so that it is advisable to the potential local pasta producers to examine the most wanted attributes of pasta products either by making further investigation or organizing panel discussion with urban dwellers of the region especially with females and professionals

We recommend any new entrants of similar line of product need to identify potential customers together with their flavor characteristics of products evaluating and making public relation programs with many ways is advised to capture people's attention/preference. Food products of pasta type are affected by factors such as manageability for cooking, content, test, structure, availability in the market, and affordability.

Thus we advise firms to take corrective action on each determinant on each identified characteristics. Currently products of pasta are dominantly available in local market such as Ashewa, Ruz Tera and other Shopping in the community which will limit the market size of the product. Thus it could also be better to have shopping centers in many places in the region to make it readily available in the mark.

Brand is the other determinants so that it is better to potential investors who intend engage in the industry including Dire Dawa food complex to consider its brand. This is due to the fact that it will divert demanders because Most of the preferred pasta like Bedriya, Bahar and others entered in to Ethiopia illegally. So the government has to take appropriate actions to the local investors so as to compute with foreign products either via strong tax punishment on contrabandists to protect local consumer or to work on scientific manner including marketing strategies, demand based production and others.

\section{Reference}

1. Asante,M.D., Asante, B.O., Acheampong, G.K., Offei, S.K., Gracen, V., Adu-Dapaah, H. \& Danquah, Y.E. (2013) Farmer and consumer preferences for rice in the Ashanti region of Ghana: Implications for rice breeding in West Africa. Journal of Plant Breeding and Crop Science, Vol 5(12), pp 229 - 238. DOI: 10.5897/JBCS13.0409

2. Bilkey, W. J. and E. Nes (1982). "Country-of-Origin Effects on Product Evaluation." Journal of International Business Studies 13(1): 89.

3. Blackwell, RD, Miniard, PW \& Engel, JF (2006). Consumer behavior, 10th edn, Thomson South-Western, Boston.

4. Diako, C., Sakyi-Dawson, E., Bediako-Amoa, B., Saalia, F.K., \& Manful J.T (2010). Consumer perceptions, knowledge and preferences for aromatic rice types in Ghana. Nat. Sci. 8(12):12-19.

5. Gideon Danso-Abbeam1 Mubarick Armed1 Francis Baidoo1 'Determinants of Consumer Preference for Local Rice in Tamale Metropolis, Ghana' International Journal of Education and Social Science www.ijessnet.com Vol. 1 No. 2; September 2014

6. Kotler, P. (2004). Ten deadly marketingsins: signs and solutions. Wiley

7. Meike Henseleit, Sabine Kubitzki, Ramona Teuber Determinants of Consume Preferences for Regional Food University of Giessen, Germany meike.henseleit@agrar.uni-giessen.de 
8. Musa, M., Othman, N., \& Abdul-Fatah, F. (2011) Determinants of Consumers Purchasing Behavior for Rice in Malaysia. American Journal of Contemporary Research,Vol 1(3), pp 159 - 167.

9. Mueller, R. D., A. J. Broderick, et al. (2001). Captious Cues: the use of misleading, deceptive or ambiguous country-of-origin cues Rene D. Mueller, Amanda J. Broderick and Rhonda Mack. Proceedings of the 30th European Academy of Marketing Conferrence. A. W. Falkenberg and K. Gronhaug. E. Breivik, The Norvwgian School of Economics and Business: 1.

10. Nadia Huitzilin Jiménez Torres Sonia San Martín Gutiérrez 'The purchase of foreign products: The role of firm's country-of-origin reputation, consumer ethnocentrism, animosity and trust.' Universidad de Burgos. Documento de trabajo 13/07

11. Nwanze, K.F., Mohapatra, S., Kormawa, P., Keya, S. \& Bruce-Oliver, S. (2006). Rice Development in subSaharan Africa. J. Sci. Food Agric. 86:675-677

12. Ogundele, O. (2014) factors influencing consumer's preference for local rice in Nigeria. African Journal of marketing Management, Vol 6(4), pp 49 - 55 DOI:10.5897/AJMM2011.048

13. Qianpin Li PhD candidate ,Consumer Attitudes towards Foreign Products: an Integrative Review of its Origins and Consequences, Edith Cowan University, Perth, Australia

14. Shapiro Philip Domie, 'Contributed Paper prepared for presentation at the 105th EAAE Seminar 'International Marketing and International Trade of Quality Food Products', Bologna, Italy, March 8-10, 2007.'

15. Thu Ha, Nguyen, Ayda Gizaw, 'Factors that influence consumer purchasing decisions of Private Label Food Products A case study of ICA Basic. Bachelor thesis in in Business Administration FOA214

16. Nanzia Florent*, Natalia Kalimang 'asi** and Robert Majula, 'Determinants of Consumers' Attitudes on Imported Products in Tanzania: The Case Study of Dodoma Municipal' International Journal of Scientific and Research Publications, Volume 4, Issue 11, November 20141 ISSN 2250-3153

17. Omar Ogenyi, 'Nigerian consumers' preferences for foreign and domestic products: examples of footwear and wlustwatches' Faculty ofBusiness, Computing \& Information Management (BCIM) London South Bank University

18. Papadopoulos, N. and L. Heslop (2003). "Country equity and country branding: Problems and prospects." Journal of Brand Management 9(4/5): 294;V314.

19. Jackson, A. (1995). "A Cross-National Investigation of Product Perception: Comparison of Products Made in China, India, Hong Kong, and the US by Respondents from Each Country." Journal of Asia-Pacific Business 1(2): 23.

20. Han, C. M. (1989). "Country image: halo or summary construct?" Journal of Marketing Research 26(2): 7.

21. Kassali, R., Kareem, R.O., Oluwasola, O. and Ohaegbulam, O.M. (2010) Analysis Of Demand For Rice in Ile Ife, Osun State, Nigeria. Journal of Sustainable Development in Africa, Vol 12(2).

22. Levin, I. P. and J. D. Jasper (1996). "Experimental analysis of nationalistic tendencies in consumer decision processes: Case of the multinational product." Journal of Experimental Psychology: Applied 2(1): 13.

23. Han, C. M. (1988). "The Role of Consumer Patriotism in the Choice of Domestic versus Foreign Products." Journal of Advertising Research 28(3): 25.

24. Marlia Musa*, Nasuddin Othman** and Fazleen Abdul Fatah***(2011).Determinants of Consumers Purchasing Behavior for Rice in Malaysia, American International Journal of Contemporary Research Vol. 1 No. 3;

25. Shapiro Philip Domie (2013).Study on factor influencing customer switch from local to imported products.

26. Nadia Huitzilin Jiménez Torres Sonia San Martín Gutiérrez. The purchase of foreign products: The role of firm's country-of-origin reputation, consumer ethnocentrism, animosity and trust. Universidad de Burgos.

27. Cordell, V.V. (1992): "Effects of Consumer Preferences for Foreign Sourced Products", Journal of International Business Studies, 23:2, pp. 251-269.

28. Diako, C., Sakyi-Dawson, E., Bediako-Amoa, B., Saalia, F.K., \& Manful J.T (2010). Consumer perceptions, knowledge and preferences for aromatic rice types in Ghana. Nat. Sci. 8(12):12-19.

29. Nwanze, K.F., Mohapatra, S., Kormawa, P., Keya, S. \& Bruce-Oliver, S. (2006). Rice Development in subSaharan Africa. J. Sci. Food Agric. 86:675-677

30. Tomlins, K.I., Manful, J.T., Larwe,r P. \& Hammond, L (2005). Urban Consumer Preferences and Sensory Evaluation of Locally Produced and Imported Rice in West Africa. Food Quality and Preference 16:79-89

\section{AUTHORS}

1. Muhammed Hamza Ali: MSc in Economics, specialized in Development Policy Analysis,

Department of Economics, Dire Dawa University- Ethiopia

PO box 1362, Dire Dawa city, Ethiopia

2. BANBUL SHEWAKENA (Assistant Professor in Financial Management).

Department of Management, Dire Dawa University, Ethiopia,

PO box 1362, Dire Dawa city, Ethiopia 